\title{
The Escherichia coli glycine transport system and its role in the regulation of the glycine cleavage enzyme system
}

\author{
Angela C. Ghrist and George V. Stauffer
}

Department of

Microbiology, The University of lowa, lowa City, IA 52242 . USA
Author for correspondence: George V. Stauffer. Tel: +1 319335 7791. Fax: +1 3193359006.

An Escherichia coli K12 mutant defective in both serine biosynthesis (serA) and glycine transport (cycA) was found to exhibit a glycine cleavage negative (GCV-) phenotype, i.e. was unable to use glycine as a serine source. While $\left[2-{ }^{14} \mathrm{C}\right]$ glycine uptake and induction of a $\lambda$ gcvT:: lacz fusion were greatly reduced in a CyCA mutant compared to the wild-type, both strains exhibited parallel increases in uptake and induction with increasing exogenous glycine concentrations. A plasmid carrying the wild-type cyc region complemented the GCV- phenotype and restored both glycine uptake and glycine-inducible gcvT:: lacZ expression. Wild-type and cycA strains grown in the presence of either a glycine-containing tripeptide or threonine, which can be degraded internally into glycine, exhibited similar induction of the gcvT: lacz fusion. However, when a gcv mutation, which causes glycine to accumulate within the cell, was introduced into the cycA strain, there was increased induction of the gcvT: : lacz fusion, but induction was less than that observed in a gcv CycA ${ }^{+}$ strain. It is proposed that cyc serves primarily in the regulation of gcv by transporting glycine into the cell, which endogenously induces gcv expression. However, the possibility of some form of exogenous regulation of gcv, mediated by the cyc-encoded glycine transport system, exists.

Keywords: Escherichia coli, glycine transport, glycine cleavage, $g c v, c y c$

\section{INTRODUCTION}

The biosynthesis of glycine and one-carbon $\left(C_{1}\right)$ units is of central physiological importance. Glycine is used in both protein and purine biosynthesis and $C_{1}$ units are needed for the biosynthesis of methionine, thymine, purines, and numerous methylated products (Stauffer, 1986). In enteric bacteria, serine hydroxymethyltransferase, the gly $A$ gene product, catalyses the conversion of serine to glycine and 5,10-methylenetetrahydrofolate (Mudd \& Cantoni, 1964; Pizer, 1965). This reaction is the cell's primary source of glycine and $\mathrm{C}_{1}$ units. A second pathway for $\mathrm{C}_{1}$ biosynthesis involves the cleavage of glycine to $\mathrm{CO}_{2}, \mathrm{NH}_{3}$ and 5,10-methylenetetrahydrofolate by the glycine cleavage (GCV) enzyme system (Sagers \& Gunsalus, 1961; Kikuchi, 1973). In balancing the cell's requirements for glycine and $\mathrm{C}_{1}$ units, GlyA and the GCV enzyme system serve important roles in cellular metabolism.

Although regulation of the $g l y A$ gene has been studied

Abbreviation: GCV, glycine cleavage. extensively (Stauffer, 1986), the regulation of $g c v$ is only just beginning to be understood. The $g c v T, g c v H$ and $g c v P$ genes encoding the GCV enzyme system are known to form an operon that maps at minute 62.5 on the Escherichia coli chromosome (Stauffer et al., 1986, 1991, 1993). The system has been shown to be inducible in the presence of exogenous glycine (Meedel \& Pizer, 1974; Wilson et al., 1993a) and repressed in the presence of exogenous purines (Wilson et al., 1993b). To date, three proteins, Lrp, PurR and $G c v A$, have been shown to be involved in the regulation of $g v v$. Lrp, or leucine-responsive regulatory protein, is a global regulatory protein involved in the control of transcription of numerous genes relating to amino acid metabolism and is required for normal induction of $g c v$ (Lin et al., 1992). PurR, or purine repressor protein, has been shown to repress the transcription of the purine biosynthetic genes (Kilstrup et al., 1989; Rolfes \& Zalkin, 1988), gly A (Steiert et al., 1990), and $g c v$ (Wilson et al., 1993b) in the presence of purines. Finally, GcvA has been shown to serve as an activator of $g c v$ in the presence of exogenous glycine and as a repressor 


\section{Table 1. Bacterial strains used in this study}

All strains were constructed in this laboratory. GS162 is a derivative of MC4100 (Casadaban, 1976).

The cycA30:: $\operatorname{Tn} 10$ allele is from CAG12073 (Singer et al., 1989). The ser $A 25$ allele is from GS395

(Plamann et al., 1983). The gcv mutation was isolated in this laboratory.

\begin{tabular}{|c|c|c|}
\hline Strain & Relevant genotype & Other markers \\
\hline GS162 & Wild-type & thi phe $A 905$ slacU169 araD129 rpsL150 \\
\hline GS780 & $\operatorname{cyc} A 30:: \operatorname{Tn} 10$ & 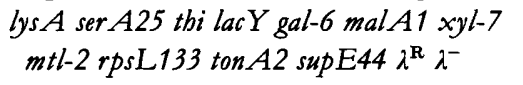 \\
\hline GS936 & $g c v$ & thi phe A905 $\Delta$ lacU169 araD129 rpsL150 \\
\hline GS958 & $\operatorname{ser} A 25$ & thi phe $A 905$ slacU169 araD129 rpsL150 \\
\hline GS988 & $\operatorname{ser} A 25$ cyc $A 30:: \operatorname{Tn} 10$ & thi phe $A 905 \Delta$ lacU169 araD129 rpsL150 \\
\hline GS989 & gcv cyc $A 30:: \operatorname{Tn} 10$ & thi phe $A 905$ DlacU169 araD129 rpsL150 \\
\hline GS990 & cyc $A 30:: \operatorname{Tn} 10$ & thi phe A905 $\Delta$ lacU169 araD129 rpsL150 \\
\hline
\end{tabular}

in the presence of exogenous purines (Wilson et al., 1993a, b).

Transport systems frequently play important roles in the regulation of gene expression (Epstein, 1983). In most cases, transport systems play a role in endogenous gene regulation by transporting effector molecules into the cell, where they are sensed by soluble or membrane-bound regulatory proteins. In other instances, membrane-spanning transport systems may exogenously regulate gene expression by producing an intracellular regulatory signal in response to the presence of extracellular effector molecules. Sensing an exogenous effector is one way of regulating gene expression by a compound in the medium when that compound is also a metabolic intermediate always present in the cell.

The E. coli glycine transport system (Cyc) has been shown to transport glycine, $\mathrm{D}$-alanine, $\mathrm{D}$-serine, and the antibiotic D-cycloserine (Wargel et al., 1970; Cosloy, 1973). Mutations in $c y c$ result in $\mathrm{D}$-cycloserine resistance and have been found to reduce the uptake of $\left[2-{ }^{14} \mathrm{C}\right]$ glycine by more than $90 \%$ as compared to the wild-type (Wargel et al., 1970; Cosloy, 1973; Robbins \& Oxender, 1973). It has been shown that this system is not inducible, but rather appears to be formed constitutively (Cosloy, 1973). Also designated dag, $c y c$ has most recently been mapped to minute 95.6 on the E. coli chromosome map (Bachmann, 1990).

In this study, the role of $c y c$ in the regulation of $g c v$ was investigated. The results suggest that $c y c$ serves primarily in the induction of $g c v$ by increasing endogenous glycine. However, the results do not rule out the possibility that cyc may also play a role in some form of exogenous induction of $g c v$.

\section{METHODS}

Bacterial strains and plasmids. All bacterial strains used in this study are E. coli $\mathrm{K} 12$ derivatives and are described in Table 1. Plasmids were constructed during this study and are described in the text.

Growth conditions. The glucose minimal (GM) medium used was the Vogel \& Bonner (1956) minimal salts medium supplemented with $0.4 \%$ glucose. The complex medium used was Luria broth (Miller, 1972). Agar was added at 1.5\% (w/v) to make solid medium. Amino acids, antibiotics and other supplements were added at the following concentrations, unless otherwise stated: leucine, isoleucine, threonine and phenylalanine, $50 \mu \mathrm{g} \mathrm{ml}^{-1}$; serine, $200 \mu \mathrm{g} \mathrm{ml}^{-1}$; glycine, $300 \mu \mathrm{g} \mathrm{ml}^{-1}$; thiamin, $1 \mu \mathrm{g} \mathrm{ml}^{-1}$; tetracycline (Tc), $10 \mu \mathrm{g} \mathrm{ml}^{-1}$; kanamycin $(\mathrm{Km}), 20 \mu \mathrm{g} \mathrm{ml}^{-1}$; chloramphenicol $(\mathrm{Cm}), 300 \mu \mathrm{g} \mathrm{m}^{-1}$; Dcycloserine, $4.0 \times 10^{-5} \mathrm{M}$. GM medium was always supplemented with phenylalanine and thiamin since most strains carry the phe $A 905$ and thi mutations. When serine was added to the medium, isoleucine was also added to overcome serine sensitivity (Uzan \& Danchin, 1978).

All $\lambda$ lysogens carry the $c$ I857 mutation resulting in a temperature sensitive repressor and were grown at $30^{\circ} \mathrm{C}$. Lysogens were tested for a single copy of bacteriophage by infection with $\lambda c \mathrm{I} 90 c 17$ (Shimada et al., 1972). All other strains were grown at $37^{\circ} \mathrm{C}$.

P1 transductions. The use of P1 $\mathrm{cml} c l r-100$ phage for transductions was as described by Miller (1972).

$\beta$-Galactosidase enzyme assays. These were performed according to Miller (1972), using the chloroform/SDS lysis procedure. Activities are expressed in Miller units.

Measurement of $\left[2-{ }^{14} \mathrm{C}\right]$ glycine uptake. Overnight cultures grown in GM medium containing appropriate supplements and antibiotics were diluted 1:100 (10 $\mathrm{ml}$ final volume) in the same medium, grown to an optical density of 100 Klett units (no. 42 filter), and transferred to screw cap test tubes. Cells were washed once in cold $0.2 \%$ GM medium, resuspended in $0.6 \mathrm{ml}$ cold $0.4 \% \mathrm{GM}$ medium, and the $\mathrm{OD}_{600}$ of $0.1 \mathrm{ml}$ of each culture determined spectrophotometrically. $\mathrm{Cm}$ was added to the remaining $0.5 \mathrm{ml}$ cells, and each tube placed on ice until all cultures had been harvested.

To begin the uptake assay, each tube containing $0.5 \mathrm{ml}$ cells was incubated for $5 \mathrm{~min}$ at $30^{\circ} \mathrm{C}$. To each tube, $\left[2-{ }^{14} \mathrm{C}\right]$ glycine $\left[0.0125 \mu{\mathrm{Ci} \mu \mathrm{g}^{-1}}^{-1}\left(2.96 \mathrm{MBq} \mathrm{\mu g}^{-1}\right) ; 800 \mu \mathrm{g} \mathrm{ml}^{-1}\right]$ and $0.4 \% \mathrm{GM}$ medium were added in amounts necessary to achieve the desired glycine concentration (final volume $2 \mathrm{ml}$ ) and incubation at $30^{\circ} \mathrm{C}$ continued. At the desired time, a $0.2 \mathrm{ml}$ sample was taken and placed in a microcentrifuge tube containing $1 \mathrm{ml} 0.4 \% \mathrm{GM}$ medium $+50 \mathrm{mM}$ unlabelled glycine prewarmed to $30^{\circ} \mathrm{C}$, centrifuged for $45 \mathrm{~s}$ and the supernatant removed. The pellet 
was resuspended in $1 \mathrm{ml} 1 \times$ minimal salts and centrifuged again for $1 \mathrm{~min}$. The supernatant was removed and the sample placed on ice until all samples had been collected. Samples were resuspended in $12 \mathrm{ml}$ scintillation cocktail and radioactivity was measured using a Beckman scintillation counter.

DNA manipulations. Isolation of phage DNA, restriction enzyme digestion, ligation, plasmid isolation and transformation were performed as described by Sambrook et al. (1989).

Materials. Restriction enzymes and other DNA modifying enzymes were from BRL or New England Biolabs. [2${ }^{14}$ C]Glycine was obtained from New England Nuclear. All other chemicals were purchased from standard commercial sources.

\section{RESULTS}

\section{Construction and analysis of a new class of $\mathrm{GCV}^{-}$ mutants}

Mutants blocked simultaneously in the serine biosynthetic pathway and the GCV pathway are unable to use glycine as a serine source (the $\mathrm{GCV}^{-}$phenotype) (Plamann et al., 1983). Therefore, it is reasonable to hypothesize that a mutant blocked simultaneously in both serine biosynthesis and glycine transport might also display the $\mathrm{GCV}^{-}$phenotype. To test this hypothesis, a $\operatorname{ser} A \operatorname{cyc} A$ double mutant was constructed by transducing the $\operatorname{cyc} A$ mutation from GS780 (cycA30:: $\operatorname{Tn} 10)$ into the $\operatorname{ser} A$ strain GS958 (ser $A 25)$ with P1 cml clr-100 phage. Transductants were selected on LB plates supplemented with $\mathrm{Tc}$, and $\mathrm{Tc}^{\mathrm{R}}$ transductants were spotted on a series of $\mathrm{GM}$ plates containing serine, glycine, or serine and $\mathrm{D}$ cycloserine. After overnight incubation (approximately $16 \mathrm{~h}$ ), all $\mathbf{T c}^{\mathbf{R}}$ transductants were capable of growing when supplemented with serine and D-cycloserine, confirming that they had acquired the cyc $A 30:: \operatorname{Tn} 10 \mathrm{mu}-$ tation conferring D-cycloserine resistance. In addition, all transductants displayed the $\mathrm{GCV}^{-}$phenotype, i.e. they exhibited normal growth when supplemented with serine, but extremely weak growth when supplemented with glycine. One such transductant was retained and designated GS988.

It should be noted that with continued incubation (approximately $24 \mathrm{~h}$ ), the transductants eventually displayed growth on GM plates supplemented with glycine. This growth may have been due in part to the high concentration of glycine used $\left(300 \mu \mathrm{g} \mathrm{ml}^{-1}\right)$. When GS988 colonies were spotted on GM plates with a lower concentration of glycine $\left(15 \mu \mathrm{g} \mathrm{ml}^{-1}\right)$, they failed to show growth after $72 \mathrm{~h}$ incubation. These observations suggest that glycine is entering the cell, but at a rate which is insufficient for normal growth.

\section{The effects of a cycA mutation on glycine uptake and induction of $g c v$}

It was initially observed that a $c y c A$ mutant defective in glycine transport still exhibited approximately $50 \%$ of the normal level of glycine-mediated induction when grown in the presence of glycine $\left(300 \mu \mathrm{g} \mathrm{ml}^{-1}\right)$ (data not shown).
Thus, it was possible that the $g c v$ system was exogenously induced by glycine. We tested this possibility and the possible role of $c y c$ in the regulation of $g c v$. The lysogen GS162 ( $\operatorname{ggc} T:: \operatorname{lac} Z$ ) carries an in-frame fusion of the $g c v T$ gene to lac $Z$ (Stauffer et al., 1993). In this fusion, $\beta$ galactosidase synthesis is under the control of the $g c v$ regulatory region. GS162( $\operatorname{ggc} v T:: \operatorname{lac} Z$ ) was transduced with P1 cml clr-100 phage grown on GS780 (cycA30:: Tn10). Transductants were selected on LB plates supplemented with $\mathrm{Tc}$, and $\mathrm{Tc}^{\mathbf{R}}$ transductants were spotted on GM plates containing D-cycloserine. All transductants were resistant to $\mathrm{D}$-cycloserine. One transductant was retained and designated GS990( $\operatorname{gcv} T:: \operatorname{lac} Z)$.

To confirm that GS990( $\operatorname{ggcv} T:: \operatorname{lac} Z)$ was defective in glycine transport, the uptake of $\left[2-{ }^{14} \mathrm{C}\right]$ glycine at 10,25 , 50,100 and $300 \mu \mathrm{g}$ glycine $\mathrm{ml}^{-1}$ was measured, with GS162 ( $\operatorname{gcc} T$ :: lac $Z$ ) serving as an isogenic control. As illustrated in Fig. 1, glycine uptake was greatly reduced in GS990 ( $\lambda g c v T:: l a c Z)$ as compared to GS162( $\lambda g c v T:: l a c Z)$ at all concentrations assayed. The greatest reduction $(83 \%)$ occurred at the lowest concentration assayed $\left(10 \mu \mathrm{g} \mathrm{ml}^{-1}\right)$. With increasing concentrations of glycine, both strains exhibited roughly parallel increases in glycine uptake, most likely due to additional routes of entry thought to exist at high concentrations of glycine $\left(>10^{-4} \mathrm{M}\right)$ (Robbins \& Oxender, 1973).

If $g c v$ expression is regulated solely by endogenous glycine, then the reduction in glycine uptake in GS990( $\operatorname{gcc} T$ : : $l a c Z$ ) should lead to a similar reduction in $g c v T:: \operatorname{lac} Z$ expression. To test this, GS162(igcvT::lacZ) and GS990( $\lambda g c v T:: l a c Z$ ) were grown in GM medium supplemented with $0,10,25,50,100$ and $300 \mu \mathrm{g}$ glycine $\mathrm{ml}^{-1}$ and assayed for $\beta$-galactosidase activity. Both strains exhibited increasing $\beta$-galactosidase activity with increasing glycine concentrations (Fig. 1). In both strains, this increase in activity was roughly paralleled by an increase in glycine uptake, suggesting that the amount of endogenous glycine is directly or indirectly responsible for induction of $g c v$.

\section{Induction of gcv by a glycine-containing tripeptide}

To provide further evidence that $g c v$ is induced endogenously by glycine, wild-type and $c y c$ strains were grown in the presence of a glycine-containing tripeptide and assayed for $\beta$-galactosidase activity. Small oligopeptides are transported into the cell via transport systems which function independently of those which transport free amino acids (Payne \& Gilvarg, 1978). Once inside the cell, these oligopeptides are then hydrolysed into free amino acids by intracellular peptidases (Payne \& Gilvarg, 1978). Since the oligopeptide transport systems in wildtype and $c y c$ strains should be functional, growth in media supplemented with a glycine-containing tripeptide should lead to similar internal glycine concentrations, and thus similar levels of $g c v$ expression. Strains GS958 $(\operatorname{ser} A)$ and GS988 $(\operatorname{ser} A \operatorname{cyc} A)$ were spotted onto GM plates supplemented with either glycine or the glycine-containing tripeptide glycine-glycine-phenylalanine. After incuba- 


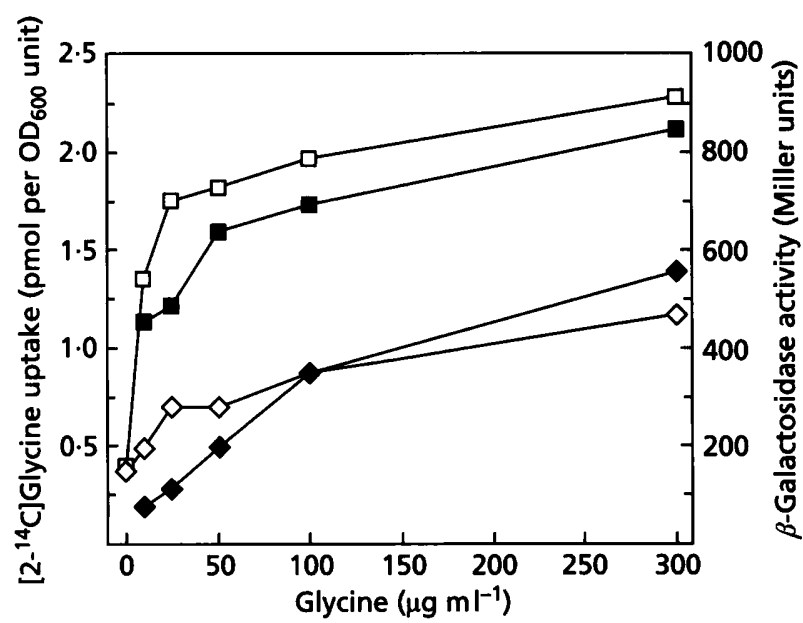

Fig. 1. $\left[2-{ }^{14} \mathrm{C}\right]$ Glycine uptake (filled symbols) and $\beta$ galactosidase activities (open symbols) of wild-type (GS162) and cyc (GS990) strains carrying the $\lambda g c v T:: l a c z$ phage. $\square, \square$, GS162; $\diamond, \diamond$, GS990. [2- $\left.{ }^{14} \mathrm{C}\right]$ Glycine uptake was measured after $10 \mathrm{~min}$ incubation. Both assays were repeated twice. Representative results are shown.

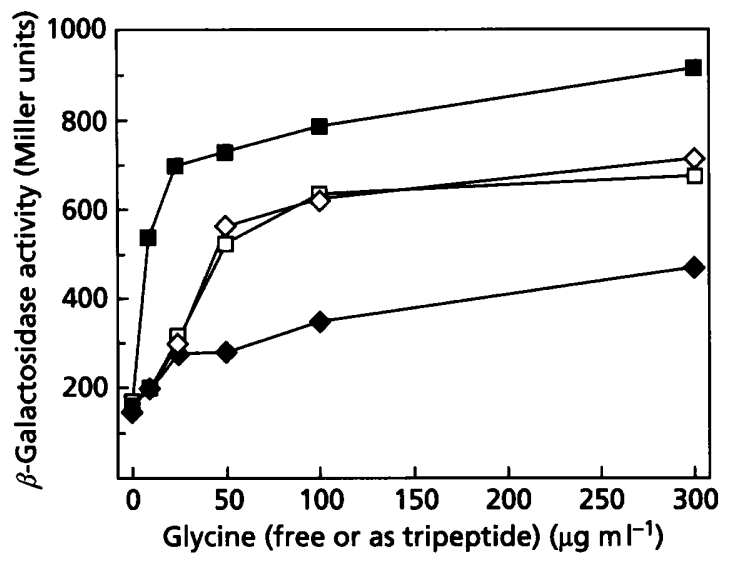

Fig. 2. $\beta$-Galactosidase activities of wild-type (GS162) and cyc (GS990) strains carrying the $\lambda g c v T$ ::lacZ phage. Filled symbols represent growth in the presence of free glycine, open symbols represent growth in the presence of glycine-glycinephenylalanine tripeptide. $\square, \square$, GS162; $\diamond, \diamond$, GS990. The assay was repeated twice. A representative result is shown.

tion overnight, GS958 was able to grow using both forms of glycine as a supplement. GS988, however, was only able to grow on the plate supplemented with the tripeptide. In another experiment, GS162( $\lambda g c v T:: l a c Z)$ (wild-type) and GS990( $\operatorname{ggc} \mathrm{T} T:: \operatorname{lac} Z)(c y c A)$ were grown in GM medium containing equimolar amounts of glycine either as the free amino acid or as the tripeptide and $\beta$ galactosidase activity was determined (Fig. 2). The induction of $\beta$-galactosidase synthesis by peptide-bound glycine was nearly identical in the two strains. It should be noted that in the wild-type strain, induction by peptide-
Table 2. $\beta$-Galactosidase activities of the wild-type (cyc $\left.c^{+}\right)$ strain and a cyc mutant carrying the $\lambda g c v T$ : :lacZ phage

\begin{tabular}{|c|c|c|c|}
\hline \multirow[t]{2}{*}{ Lysogen } & \multicolumn{3}{|c|}{$\begin{array}{c}\beta \text {-Galactosidase activity* } \\
\text { (Miller units) }\end{array}$} \\
\hline & $\mathbf{G M}$ & $\begin{array}{c}\text { GM + threonine } \\
\left(15 \mu \mathrm{g} \mathrm{ml}^{-1}\right)\end{array}$ & $\begin{array}{c}\text { GM + threonine } \\
\left(50 \mu \mathrm{g} \mathrm{ml}^{-1}\right)\end{array}$ \\
\hline \multicolumn{4}{|l|}{ GS162 $\left(c y c^{+}\right)$} \\
\hline Minus leucine & 172 & 261 & 394 \\
\hline Plus leucine & 171 & 261 & 448 \\
\hline \multicolumn{4}{|l|}{ GS990 (cyc) } \\
\hline Minus leucine & 165 & 248 & 268 \\
\hline Plus leucine & 174 & 265 & 308 \\
\hline
\end{tabular}

* Cells were grown in GM medium with or without leucine and with or without threonine at the indicated concentrations. All results are means from at least two separate trials in which each sample was determined in triplicate. All standard deviations were within $12 \%$ of the mean.

bound glycine was significantly less than that exhibited in the presence of an equimolar amount of free glycine.

\section{Induction of $g c v$ by threonine}

Another means of increasing internal glycine independent of $c y c$ is to grow cells in the presence of threonine. Threonine enters the cell via a transport system distinct from that which transports glycine (Robbins \& Oxender, 1973; Templeton \& Savagean, 1974). Inside the cell, threonine may then be degraded to glycine and acetyl coenzyme $\mathrm{A}$ by threonine dehydrogenase, encoded by $t d h$, and $\alpha$-amino- $\beta$-ketobutyrate lyase (Newman et al., 1976; Potter et al., 1977). This pathway has been shown to provide an alternative route for glycine biosynthesis (Ravnikar \& Sommerville, 1987). The conversion of threonine to glycine can be increased by the addition of leucine, as leucine has been shown to relieve $\operatorname{lr} p$-mediated repression of $t d h$ (Rex et al., 1991). Leucine alone has been shown to have no effect on gcv expression (Lin et al., 1992).

If $g c v$ is induced by endogenous glycine, then wild-type and $c y c A$ strains should have similar levels of induction when grown in the presence of either threonine or threonine and leucine. GS162 ( $\operatorname{ggc} T$ :: lacZ) (wild-type) and GS990( $\operatorname{dgcv} T:: \operatorname{lac} Z)(c y c A)$ were grown in GM medium either with or without leucine and either with or without low $\left(15 \mu \mathrm{g} \mathrm{ml}^{-1}\right)$ and high $\left(50 \mu \mathrm{g} \mathrm{ml}^{-1}\right)$ levels of threonine and assayed for $\beta$-galactosidase activity. As shown in Table 2, the wild-type and $c y c A$ lysogens were not induced in the presence of leucine alone. Both lysogens displayed similar induction by threonine $\left(15 \mu \mathrm{g} \mathrm{ml}^{-1}\right)$ in the presence or absence of leucine. When threonine was used at $50 \mu \mathrm{g} \mathrm{ml}^{-1}$, induction of $g c v$ was higher in both lysogens, although induction was significantly lower in the $c y c A$ lysogen compared to the wildtype. In addition, the presence of leucine and threonine resulted in slightly higher levels of induction in both lysogens. 
Table 3. $\beta$-Galactosidase activities of wild-type, gcv and cyc strains carrying the $\lambda g c v T::$ lac $Z$ phage

\begin{tabular}{|clrc|}
\hline Lysogen & $\begin{array}{l}\text { Relevant } \\
\text { genotype }\end{array}$ & \multicolumn{2}{c|}{$\begin{array}{c}\boldsymbol{\beta} \text {-Galactosidase } \\
\text { activity* } \\
\text { (Miller units) }\end{array}$} \\
\cline { 3 - 4 } & & GM & GM+ glycine \\
\hline GS162 & $\left(g c v^{+} c y c^{+}\right)$ & 202 & 1141 \\
GS936 & $\left(g c v c y c^{+}\right)$ & 1645 & 1772 \\
GS990 & $\left(g c v^{+} c y c\right)$ & 184 & 725 \\
GS989 & $(g c v c y c)$ & 1140 & 1648 \\
\hline
\end{tabular}

* Cells were grown in GM medium with or without glycine $\left(300 \mu \mathrm{g} \mathrm{ml}^{-\mathbf{1}}\right)$. All results are means from at least two separate trials in which each sample was determined in triplicate. All standard deviations were within $8 \%$ of the mean.

\section{gcvT::lacZ expression in a gcv cycA double mutant}

Lysogen GS936( $\operatorname{gcv} T:: \operatorname{lac} Z)$ is a $g c v$ mutant. This strain exhibits a high level of induction of a $g c v T:$ : lac $Z$ fusion as measured by $\beta$-galactosidase activity, even in the absence of exogenous glycine (Table 3 ). This is presumably due to the accumulation of glycine within the cell, since GS936( $\lambda g c v T:$ : lac $Z$ ) secretes glycine, as evidenced by its ability to feed a glycine auxotroph (data not shown). Transformation of this strain with a plasmid carrying a functional GCV enzyme system returned the induction of $\beta$-galactosidase synthesis to wild-type levels (data not shown).

If the induction of $g c v$ is due solely to internal glycine, then a gcv $c y c A$ double mutant should have levels of induction similar to those observed in a $g c v$ mutant, as internal glycine levels should be essentially the same. To test this hypothesis, a $g c v c y c A$ double mutant was constructed by transducing GS936( $\mathrm{gcv} T:: \mathrm{lac} Z)(\mathrm{gcv})$ with P1 $\mathrm{cml} \mathrm{clr}-100$ phage grown on GS780 (cycA30::Tn10). Transductants were selected on LB plates supplemented with Tc and $\mathrm{Tc}^{\mathrm{R}}$ transductants were then spotted on GM plates supplemented with D-cycloserine. One D-cycloserineresistant transductant was retained and designated GS989( $\lambda g c v T::$ lac $Z$ ). This strain secreted glycine at a level similar to that observed in GS936( $\operatorname{gcv} T::$ lacZ), as measured by its ability to feed a glycine auxotroph (data not shown).

Table 3 shows $\beta$-galactosidase activities for

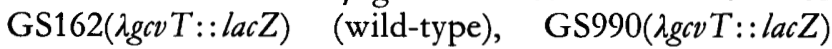
$(c y c A), \mathrm{GS} 936(\lambda g c v T:: \operatorname{lac} Z)(g c v)$, and GS989( $\lambda g c v T:: \operatorname{lac} Z)$ $(c y c A g c v)$ grown in GM medium with and without glycine. $\beta$-Galactosidase activity was greater in GS989( $\operatorname{gcv} T:: \operatorname{lac} Z$ ) than it was in GS990( $\operatorname{gcc} T::$ lacZ) in both uninduced and glycine-induced cultures, presumably due to a higher endogenous glycine concentration. However, $\beta$-galactosidase activities in strain GS989( $\lambda g c v T::$ lacZ) were still significantly lower than those in strain GS936( $\lambda g c v T:: \operatorname{lac} Z)$ in both uninduced and induced cultures.

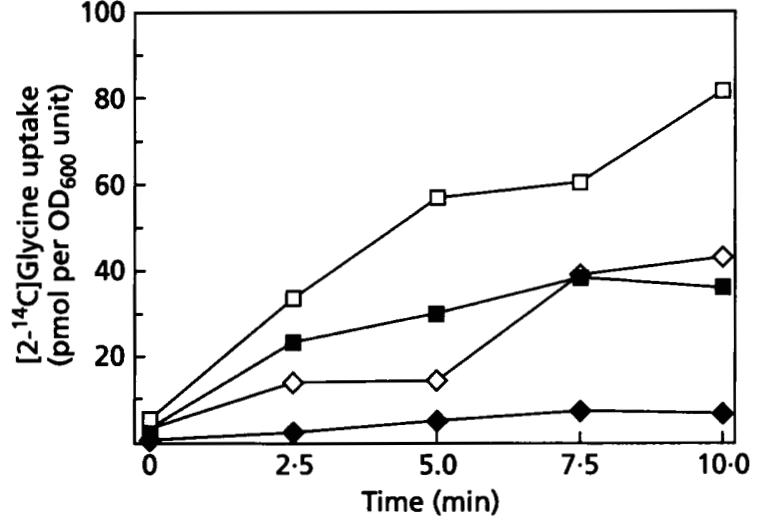

Fig. 3. Complementation of the glycine-uptake deficiency in the cyc mutant by the single-copy plasmid pGS260 carrying the wild-type cyc gene. The concentration of glycine used was $15 \mu \mathrm{g} \mathrm{ml}^{-1}$. Filled symbols represent $\left[2-{ }^{14} \mathrm{C}\right] \mathrm{glycine}$ uptake by untransformed strains, open symbols represent that of strains transformed with pGS260. $\square, \square$, GS162; $\diamond, \diamond$, GS990. Both strains carry a $\lambda g c v T::$ lac $Z$ fusion. The assay was repeated twice. A representative result is shown.

\section{Cloning cyc}

The glycine transport system was cloned using the 'Miniset' of specialized transducing bacteriophages described by Kohara et al. (1987). In brief, a series of bacteriophages containing $E$. coli DNA covering the known map position of $c y c$ were spotted on a lawn of GS988 $(\operatorname{ser} A \operatorname{cyc} A)$ growing on GM plates containing glycine $\left(25 \mu \mathrm{g} \mathrm{ml}^{-1}\right)$. Since GS988 is unable to transport sufficient glycine for growth, only those cells containing a functional transport system from the $\lambda$ bacteriophage should be able to grow. One such bacteriophage, 7E9, complemented the $\mathrm{GCV}^{-}$phenotype. DNA was prepared from this phage and digested with BamHI. The $17 \mathrm{~kb}$ insert was isolated and ligated into the $\mathrm{BamHI}$ site of the single-copy plasmid pGS225, a pDF41 derivative (Kahn et al., 1979) containing a $\operatorname{Tn} 5$ : : kan gene (Berg et al., 1975). This new plasmid was designated pGS260.

The ability of pGS260 to complement a $\mathrm{GCV}^{-}$phenotype was tested by transforming strain GS988. Transformants were selected on LB plates supplemented with $\mathrm{Km}$ and Tc. When the transformants were spotted on GM plates supplemented with glycine, pGS260 was able to complement the $\mathrm{GCV}^{-}$phenotype.

To confirm that pGS260 was capable of restoring normal glycine transport, the uptake of $\left[2-{ }^{14} \mathrm{C}\right]$ glycine was measured for GS162( $\lambda g c v T::$ lacZ) (wild-type) and GS990( $\operatorname{gcv} T:: \operatorname{lac} Z)(c y c A)$ transformed with pGS260; the untransformed strains served as controls. GS990( $\operatorname{gcv} T::$ lacZ) transformed with pGS260 displayed near normal glycine transport (Fig. 3), and GS162( $\operatorname{gcv} T::$ lacZ) transformed with pGS260 exhibited glycine uptake greater than that observed in the untransformed strain, suggesting that pGS260 carries the cyc-encoded glycine transport system. 
Table 4. $\beta$-Galactosidase activities of wild-type, gcv and cyc strains carrying the $\lambda g c v T:: l a c Z$ phage and transformed with pGS260

\begin{tabular}{|c|c|c|c|}
\hline \multirow[t]{2}{*}{ Strain } & \multirow[t]{2}{*}{$\begin{array}{l}\text { Relevant } \\
\text { genotype }\end{array}$} & \multicolumn{2}{|c|}{$\begin{array}{c}\boldsymbol{\beta} \text {-Galactosidase } \\
\text { activity* } \\
\text { (Miller units) }\end{array}$} \\
\hline & & GM & GM+glycine \\
\hline GS162(pGS260) & $\left(g c v^{+} c y c^{+} / c y c^{+}\right)$ & 166 & 1538 \\
\hline GS990(pGS260) & $\left(g c v^{+} c y c / c y c^{+}\right)$ & 178 & 1199 \\
\hline GS989(pGS260) & $\left(g c v c y c / c y c^{+}\right)$ & 1645 & 1856 \\
\hline
\end{tabular}

* Cells were grown in GM medium with or without glycine $\left(300 \mu \mathrm{g} \mathrm{ml}^{-1}\right)$. All results are means from at least two separate trials in which each sample was determined in triplicate. All standard deviations were within $12 \%$ of the mean.

\section{Induction of gcv in wild-type and cyc strains transformed with pGS260}

Plasmid pGS260 was used to transform lysogens

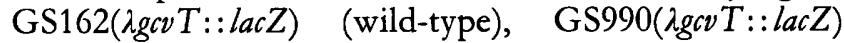
$(c y c A)$, and GS989 ( $\operatorname{gcc} T:: \operatorname{lac} Z)(g c v c y c A)$. Transformants were then grown in GM medium with or without glycine and assayed for $\beta$-galactosidase activity. As shown in Table 4, pGS260 complemented the cyc $A$ mutation in lysogen GS990 ( $\lambda g c v T:: \operatorname{lac} Z)$, increasing the induction of $g c v T:: l a c Z$ by glycine to the level found in GS162( $\operatorname{gcc} T$ : : lacZ) (see Table 3). The plasmid was also able to complement the $c y c A$ mutation in GS989 ( $\operatorname{ggcv} T:: \operatorname{lac} Z$ ), increasing the induction of $g c v T::$ lac $Z$ in the absence of glycine to that observed in GS936( $\operatorname{gcc} T$ ::LacZ) (see Table 3). In addition, introducing an additional copy of cyc via pGS260 into GS162 ( $\operatorname{ggcv} T:: \operatorname{lac} Z$ ) increased the induction of $g c v T:: \operatorname{lac} Z$ by glycine over that observed when only a single copy of $c y c$ was present (see Table 3), suggesting that at least part of the increased induction of $g c \nu T:: l a c Z$ by glycine in the transformed strain results from an increase in glycine transport.

\section{DISCUSSION}

The glycine transport system appears to serve primarily in the regulation of $g c v$ by transporting glycine into the cell, where endogenous induction of $g c v$ expression occurs. In many ways, this regulation is similar to the endogenous regulation of proline oxidase (put $A$ ), a proline degradation enzyme, by the proline transport system (putP) (Ratzkin et al., 1978). In this system, proline is transported into the cell by the putP transport system, where it then induces both putP and put $A$. A putP mutant, which lacks proline oxidase activity in the uninduced state, secretes proline, suggesting that a functional proline transport system is required to maintain internal proline pools. Mutants blocked simultaneously in proline biosynthesis and proline transport grow very poorly, even when supplied with high concentrations of proline. This is similar to the inability of a $\operatorname{ser} A \operatorname{cyc} A$ mutant to use glycine as a glycine/serine source. A putP mutant grown in the presence of proline exhibits as much as a $99 \%$ reduction in proline uptake compared to the wild-type, yet still exhibits a slight induction of both putP and put $A$, presumably due to diffusion, residual transport or secondary transport of proline into the cell. This is similar to the ability of glycine to induce $g c v$ in a $c y c$ mutant, even though glycine uptake is greatly reduced.

Despite similarities to the put system, several observations leave open the possibility that part of the induction signal is exogenous. When wild-type and put $P$ strains were grown in the presence of a proline-containing dipeptide, induction of putP and put $A$ was the same in both strains and was not significantly different from that observed when the wild-type strain was grown in the presence of free proline (Ratzkin et al., 1978). When wild-type and cyc strains were grown in the presence of a glycine-containing tripeptide, induction of $g c v$ was the same in both strains (Fig. 2). However, this induction was significantly less than that observed when the wild-type strain was grown in an equimolar amount of free glycine. This difference in induction may be due to an exogenous induction signal by glycine, which would be absent in the case of induction by peptide-bound glycine. Another explanation is that peptide-bound glycine is transported less efficiently than free glycine or that the conversion of tripeptide to free glycine is limiting. It is also possible that free glycine is able to induce $g c v$ more efficiently than peptide-bound glycine due to an association of the glycine transport system with Gcv or GcvA.

Another observation which may indicate partial exogenous induction is that $g c v$ mutants excrete glycine into the growth medium, presumably an indication that internal glycine pools are saturated. However, expression of $g c v$ was significantly elevated in a $g c v c y c^{+}$strain compared to a gcv cyc strain grown in GM medium (Table 3). This may be due to the inability of the $g c v c y c$ strain to maintain an internal glycine concentration equal to that of the $\mathrm{gcv}$ strain. It is also possible that, in the case of the $g c v$ strain, glycine secreted into the growth medium induces $g c v$ exogenously. If exogenous induction occurs, it appears to require a functional glycine transport system.

Our results also show that threonine induces the $\mathrm{gcv}$ operon (Table 2). This is most likely an indirect effect caused by the conversion of threonine to glycine (Ravnikar \& Sommerville, 1987). This conclusion is supported by the increase in induction observed when both leucine and threonine were added to the growth medium (Table 2). Leucine has previously been shown to increase the conversion of threonine to glycine (Rex et al., 1991). It should be noted that threonine supplementation results in lower levels of $g c v T:: \operatorname{lac} Z$ expression in the $c y c$ mutant than in the $c y c^{+}$strain. This may again be due to the inability of the $c y c$ mutant to maintain a high internal glycine concentration. Another possibility is that the wild-type glycine transport system is also capable of the nonspecific transport of threonine when threonine is present at high concentrations. 
The cloned E. coli glycine transport system will allow us to investigate in more detail the possibility of both endogenous and exogenous induction of the GCV enzyme system, and the role that the $c y c$-encoded glycine transport system plays in $g c v$ induction.

\section{ACKNOWLEDGEMENTS}

This investigation was supported by Public Health Service grant GM26878 from the National Institute of General Medical Sciences.

\section{REFERENCES}

Bachmann, B. J. (1990). Linkage map of Eschericbia coli K-12, edition 8. Microbiol Rev 54, 130-197.

Berg, D. E., Davies, J., Allet, B. \& Rochaix, J. D. (1975). Transposition of $\mathrm{R}$ factor genes to bacteriophage $\lambda$. Proc Natl Acad Sci US A 72, 3628-3632.

Casadaban, M. (1976). Transposition and fusion of the lac genes to selected promoters in Escherichia coli using bacteriophage lambda and Mu. J Mol Biol 104, 541-556.

Cosloy, S. D. (1973). D-Serine transport system in Escherichia coli K12. $J$ Bacteriol 114, 679-684.

Epstein, W. (1983). Membrane-mediated regulation of gene expression in bacteria. In Gene Function in Prokaryotes, pp. 281-292. Edited by J. Beckwith, J. Davies \& J. Gallant. Cold Spring Harbor, NY: Cold Spring Harbor Laboratory.

Kahn, M., Kolter, R., Thomas, C., Figurski, D., Meyer, R., Remaut, E. \& Helinski, D. R. (1979). Plasmid cloning vehicles derived from plasmids ColE1, F, R6K and RK2. Methods Enzymol 68, 268-280.

Kikuchi, G. (1973). The glycine cleavage system: composition, reaction mechanism, and physiological significance. Mol Cell Biochem 1, 169-187.

Kilstrup, M., Meng, L. M., Neuhard, J. \& Nygaard, P. (1989). Genetic evidence for a repressor of synthesis of cytosine deaminase and purine biosynthesis enzymes in Eschericbia coli. J Bacteriol 171, 2124-2127.

Kohara, Y., Akiyama, K. \& Isono, K. (1987). The physical map of the whole $E$. coli chromosome: application of a new strategy for rapid analysis and sorting of a large genomic library. Cell 50, 495-508.

Lin, R., D'Ari, R. \& Newman, E. B. (1992). גplac Mu insertions in genes of the leucine regulon: extension of the regulon to genes not regulated by leucine. J Bacteriol 174, 1948-1955.

Meedel, T. H. \& Pizer, L. I. (1974). Regulation of one-carbon biosynthesis and utilization in Escherichia coli. J Bacteriol 118, 905-910.

Miller, J. H. (1972). Experiments in Molecular Genetics. Cold Spring Harbor, NY: Cold Spring Harbor Laboratory.

Mudd, S. H. \& Cantoni, G. L. (1964). Biological transmethylation, methyl-group neogenesis, and other "one-carbon" metabolic reactions dependent upon tetrahydrofolic acid. In Comprehensive Biochemistry, pp. 1-47. Edited by M. Florkin \& E. H. Stotz. Amsterdam: Elsevier.

Newman, E. B., Kapoor, V. \& Potter, R. (1976). Role of L-threonine dehydrogenase in the catabolism of threonine and synthesis of glycine by Escherichia coli. J Bacteriol 126, 1245-1249.

Payne, J. W. \& Gilvarg, C. (1978). Transport of peptides in bacteria. In Bacterial Transport, pp. 325-383. Edited by B. P. Rosen. New York: Marcel Dekker.
Pizer, L. I. (1965). Glycine synthesis and metabolism in Escherichia coli. J Bacteriol 89, 1145-1150.

Plamann, M. D., Rapp, W. D. \& Stauffer, G. V. (1983). Escherichia coli K12 mutants defective in the glycine cleavage enzyme system. Mol \& Gen Genet 192, 15-20.

Potter, R., Kapoor, V. \& Newman, E. B. (1977). Role of threonine dehydrogenase in Escherichia coli threonine degradation. J Bacteriol 132, 385-391.

Ratzkin, B., Grabnar, M. \& Roth, J. (1978). Regulation of the major proline permease gene of Salmonella typhimurium. J Bacteriol 133, 737-743.

Ravnikar, P. D. \& Somerville, R. L. (1987). Genetic characterization of a highly efficient alternate pathway of serine biosynthesis in Escherichia coli. J Bacteriol 169, 2611-2617.

Rex, J. H., Aronson, B. D. \& Somerville, R. L. (1991). The $t d h$ and $\operatorname{ser} A$ operons of Escherichia coli: mutational analysis of the regulatory elements of leucine-responsive genes. $J$ Bacteriol 173, 5944-5953.

Robbins, J. C. \& Oxender, D. L. (1973). Transport systems for alanine, serine, and glycine in Escherichia coli K-12. J Bacteriol 116, $12-18$.

Rolfes, R. J. \& Zalkin, H. (1988). Escherichia coli gene purR encoding a repressor protein for purine nucleotide synthesis. $J$ Biol Chem $\mathbf{2 6 3}$, 19653-19661.

Sagers, R. D. \& Gunsalus, I. C. (1961). Intermediary metabolism of Diplococcus glycinopbilus. I. Glycine cleavage and one-carbon interconversions. J Bacteriol 81, 541-549.

Sambrook, J., Fritsch, E. F. \& Maniatis, T. (1989). Molecular Cloning: a Laboratory Manual. Cold Spring Harbor, NY: Cold Spring Harbor Laboratory.

Shimada, K., Weisberg, R. A. \& Gottesman, M. E. (1972). Prophage $\lambda$ at unusual chromosomal locations. I. Location of the secondary attachment sites and the properties of the lysogens. J Mol Biol 63, 483-503.

Singer, M., Baker, T. A., Schnitzler, G., Deischel, S. M., Goel, M., Dove, W., Jaacks, K. J., Grossman, A. D., Erickson, J. W. \& Gross, C. A. (1989). A collection of strains containing genetically linked alternating antibiotic resistance elements for genetic mapping of Escherichia coli. Microbiol Rev 53, 1-24.

Stauffer, G. V. (1986). Biosynthesis of serine and glycine. In Escherichia coli and Salmonella typhimurium: Cellular and Molecular Biology, pp. 412-418. Edited by J. L. Ingraham, K. B. Low, B. Magasanik, M. Schaechter, H. E. Umbarger \& F. C. Neidhardt. Washington, DC: American Society for Microbiology.

Stauffer, L. T., Plamann, M. D. \& Stauffer, G. V. (1986). Cloning and characterization of the glycine-cleavage enzyme system of Escherichia coli. Gene 44, 219-226.

Stauffer, L. T., Steiert, P. S., Steiert, J. G. \& Stauffer, G. V. (1991), An Escherichia coli protein with homology to the H-protein of the glycine cleavage enzyme complex from pea and chicken liver. DNA Sequence 2, 13-17.

Stauffer, L. T., Ghrist, A. C. \& Stauffer, G. V. (1993). The Escherichia coli gcvT gene encoding the $\mathrm{T}$-protein of the glycine cleavage enzyme system. DNA Sequence-J DNA Sequencing Mapping 3, $339-346$

Steiert, J. G., Rolfes, R. J., Zalkin, H. \& Stauffer, G. V. (1990). Regulation of the Escherichia coli gly $A$ gene by the purR gene product. J Bacteriol 172, 3799-3803.

Templeton, B. A. \& Savagean, M. A. (1974). Transport of biosynthetic intermediates: homoserine and threonine uptake in Escherichia coli. J Bacteriol 117, 1002-1009. 
Uzan, M. \& Danchin, A. (1978). Correlation between the serine sensitivity and the derepressibility of the $i l v$ genes in Escherichia coli relA mutants. Mol \& Gen Genet 165, 21-30.

Vogel, H. J. \& Bonner, D. M. (1956). Acetylornithinase of Escherichia coli: partial purification and some properties. $J$ Biol Chem 218, 97-106.

Wargel, R. J., Shadur, C. A. \& Neuhaus, F. C. (1970). Mechanism of D-cycloserine action : transport systems for D-alanine, D-cycloserine, L-alanine, and glycine. $J$ Bacteriol 103, 778-788.
Wilson, R. L., Steiert, P. S. \& Stauffer, G. V. (1993a). Positive regulation of the Escherichia coli glycine cleavage enzyme system. $J$ Bacteriol 175, 902-904.

Wilson, R. L., Stauffer, L. T. \& Stauffer, G. V. (1993b). Roles of the GcvA and PurR proteins in negative regulation of the Escherichia coli glycine cleavage enzyme system. J Bacteriol 175, 5129-5134.

Received 22 April 1994; revised 3 August 1994; accepted 24 August 1994. 